\title{
EFEKTIVITAS MODEL PEMBELAJARAN QUANTUM TEACHING TERHADAP HASIL BELAJAR FISIKA
}

\author{
Ovilia Putri Utami Gumay ${ }^{1}$, Nindya Heidi ${ }^{2}$, Ahmad Amin ${ }^{3}$, \\ Program Studi Pendidikan Fisika STKIP PGRI Lubuklinggau ${ }^{1,2,3}$ \\ oviliaputri@stkippgri-lubuklinggau.ac.id ${ }^{1}$
}

Submit, 30-11-2018 Accepted, 28-12-2018 Publish, 28-12-2018

\begin{abstract}
: this study aims to determine the completeness of learning outcomes and student learning activities on learning physics with Quantum Teaching learning model. The method used is experiment. The population to be used in this research is all students of class $X$ computer network technique. Class $X$ computer network technique 1 as a sample in this study. Data collection techniques used are test and observation techniques. Data were analyzed using $t$-test. based on result of $t$-test analysis obtained $t_{\text {count }}{ }^{>}$ $t_{\text {table }}=(4,206>1,6973)$ which means $H_{a}$ accepted. So it can be concluded that the Use of Learning Model Quantum Teaching effective against Physics Learning Outcomes Students class X vocational high school state 3 Lubuklinggau Lesson year 2017/2018. Student learning activity in good category.
\end{abstract}

Keywords: Student learning activities, Physics Learning Outcomes, Quantum Teaching

\begin{abstract}
Abstrak: penelitian ini bertujuan untuk mengetahui ketuntasan hasil belajar dan aktifitas belajar siswa pada pembelajaran fisika dengan model pembelajaran Quantum Teaching. Metode yang digunakan adalah eksperimen. Populasi yang akan digunakan dalam penelitian ini adalah seluruh siswa kelas X TKJ. Kelas $X$ TKJ 1 sebagai sampel dalam penelitian ini. Teknik pengumpulan data yang digunakan adalah teknik tes dan observasi. Data dianalisis dengan menggunakan uji-t. berdasarkan hasil analisis uji-t diperoleh $t_{\text {hitung }}$ $>t_{\text {tabel }}=(4,206>1,6973)$ yang berarti $H_{a}$ diterima. Sehingga dapat disimpulkan bahwa Penggunaan Model Pembelajaran Quantum Teaching efektif terhadap Hasil Belajar Fisika Siswa kelas X SMK Negeri 3 Lubuklinggau Tahun Pelajaran 2017/2018. Aktivitas belajar siswa dalam kategori baik.
\end{abstract}

Kata kunci : Aktivitas belajar siswa, Hasil Belajar Fisika, Quantum Teaching

\section{PENDAHULUAN}

Tujuan Pendidikan Nasional seperti yang telah dijelaskan di Undang-Undang Nomor 20 tahun 2003 Pasal 3 merupakan tujuan yang bersifat paling umum dan merupakan sarana akhir yang harus dijadikan pedoman oleh setiap usaha pendidikan. Artinya, setiap lembaga dan penyelanggara pendidikan harus dapat membentuk manusia yang sesuai dengan rumusan undang-undang tersebut, baik pendidikan yang diselenggarakan oleh lembaga pendidikan formal, informal maupun nonformal.

Dalam dunia pendidikan tentu kita memiliki kendala terutama dalam meningkatkan mutu pendidikan di Indonesia. Peningkatan mutu pendidikan dapat dilihat dari hasil belajar. Salah satu masalah pokok dalam meningkatkan mutu pendidikan adalah dalam pembelajaran pada pendidikan formal (sekolah) saat ini masih sangat rendah daya serap siswa

Berdasarkan hasil observasi dan wawancara tentang proses belajar dan hasil belajar siswa yang dilakukan di SMK Negeri 3 Lubuklinggau pada tanggal 18 Agustus 2017, dengan nara sumber yaitu Bapak A. Budi Mulyanto, M.Pd. selaku guru bidang studi fisika. Dari keterangan diketahui Kriteria Ketuntasan Minimum (KKM) yang 
ditetapkan di SMK Negeri 3 Lubuklinggau untuk pelajaran fisika adalah sebesar 75. Sementara itu hasil belajar yang didapat oleh siswa berdasarkan keterangan dari guru fisika sekolah tersebut, dari 108 siswa hanya 40 siswa (sekitar $40 \%$ ) yang mencapai KKM. Itu artinya pencapaian nilai KKM yang diharapkan belum tercapai secara optimal, karena masih 68 siswa (60\%) yang nilainya di bawah KKM.

Agar tujuan pembelajaran tercapai perlu memilih model pembelajaran yang tepat. Salah satu model pembelajaran yang diharapkan dapat meningkatkan hasil belajar siswa pada pelajaran fisika dan meningkatkan keaktifan siswa adalah model pembelajaran Quantum Teaching.

\section{LANDASAN TEORI}

Quantum Teaching merupakan
model pembelajaran aktif yang dikembangkan oleh Bobbi DePorter, Mark Reardon, dan Sarah Singer-Nourie. Quantum Teaching adalah pengubahan bermacam-macam interaksi yang ada di dalam dan di sekitar momen belajar (DePorter dkk, 2014).

Menurut Hertanti (2013) model pembelajaran Quantum Teaching menekankan pada hubungan dinamis dalam lingkungan belajar, di mana akan tercipta suasana belajar yang menyenangkan, sehingga siswa mempunyai kemauan untuk terlibat secara aktif dalam melalui tahapan dalam Quantum Teaching. Hal ini sejalan dengan Siregar dan Juliani (2014) menerangkan bahwa model pembelajaran Quantum Teaching adalah model pembelajaran yang menyenangkan di mana interaksi antara guru dengan siswa berjalan dengan baik.

Menurut DePorter pada model pembelajaran Quantum Teaching memiliki kerangka rancangan belajar yang biasa dikenal dengan kata TANDUR. TANDUR merupakan singkatan dari tumbuhkan, alami, namai, demonstrasikan, ulangi, dan rayakan. Berikut ini merupakan penjelasan tentang TANDUR dan maknanya menurut DePorter (dalam Rusman, 2014):

1. Tumbuhkan. Berarti menumbukan minat belajar siswa dengan cara memberitahukan manfaat materi yang akan dipelajari. Bertujuan untuk menumbuhkan minat siswa dan menimbulkan pertanyaan "Apakah Manfaat Bagiku" (AMBAK) dalam diri siswa

2. Alami. Berikan mereka pengalaman belajar untuk mengalaminya sendiri.

3. Namai. Berikan "data" tepat ketika minat memuncat.

4. Demonstrasikan. Berikan kesempatan bagi mereka untuk mengaitkan pengalaman dengan data baru, sehingga mereka menghayati dan membuatnya sebagai pengalaman pribadi.

5. Ulangi Rekatkan gambaran keseluruhannya dengan retensi.

6. Rayakan. Perayaan menambahkan belajar dengan asosiasi positif. Berikan penghargaan atas prestasi yang positif, sehingga terus diulangi.

Quantum Teaching memiliki lima prinsip, atau kebenaran tetap. Prinsipprinsip ini mempengaruhi seluruh aspek Quantum Teaching. Menurut (DePorter dkk, 2014). Prinsip-prinsip tersebut adalah sebagai berikut:

1. Segalanya berbicara. Segalanya dari lingkungan kelas hingga bahasa tubuh, dari kertas yang dibagikan hingga rancangan pelajaran semuanya mengirim pesan tentang belajar.

2. Segalanya bertujuan. Semua yang terjadi dalam pengubahannya mempunyai tujuan.

3. Pengalaman sebelum pemberian nama

Otak kita berkembang pesat dengan adanya rangsangan kompleks, yang akan mengerakan rasa ingin tau. Oleh karena itu, proses belajar paling baik terjadi ketika siswa telah mengalami informasi sebelum mereka 
memperoleh nama untuk apa yang mereka pelajari.

1. Akui setiap usaha. Belajar mengandung resiko. Belajar berarti melangkah keluar dari kenyamanan. Pada saat siswa mengambil langkah ini, mereka patut mendapat pengakuan atas kecakapan dan kepercayaan diri mereka.

2. Jika layak dipelajari, maka layak pula dirayakan

Perayaan adalah sarapan pelajar juara. Perayaan memberikan umpan balik mengenai kemajuan dan meningkatkan asosiasi emosi positif dengan belajar.

\section{METODE PENELITIAN}

Pada penelitian ini peneliti menggunakan metode penelitian eksperimen. Menurut Arikunto (2013) penelitian eksperimen adalah suatu cara untuk mencari hubungan sebab akibat. Bentuk desian dalam penelitian ini adalah one group pretest-postest design yang digambarkan oleh Arikunto (2010) tabel 1.

Tabel 1. one group pretest-postest design

\begin{tabular}{ccc}
\hline Pretest & Treatment & Posttest \\
\hline $\mathrm{O}_{1}$ & $\mathrm{X}$ & $\mathrm{O}_{2}$ \\
\hline
\end{tabular}

Dalam penelitian ini terdapat dua variabel yaitu variabel bebas (X) dan variabel terikat $(\mathrm{O})$. Varibel bebas adalah variabel yang bersifat mempengaruhi variabel terikat. Variabel bebas dalam penelitian ini adalah model pembelajaran Quantum Teaching (Arikunto, 2010). Variabel terikat adalah yang bersifat dipengaruhi oleh variabel bebas. Variabel terikat dalam penelitian ini adalah hasil belajar fisika siswa (Arikunto, 2010).

Populasi dalam penelitian ini adalah seluruh siswa kelas X TKJ SMK Negeri 3 Lubuklinggau yang berjumlah 108 orang siswa. Pengambilan sampel dilakukan dengan teknik simple random sampling cara demikian dilakukan karena anggota populasi memiliki tingkat kemampuan yang sama.
Teknik pengumpulan data yang dilakukan adalah tes dan observasi teknik analisa data yang digunakan dalam penelitian ini adalah Teknik tes dilakukan dengan memberikan soal berbentuk essay sebanyak 10 soal pada kelas uji coba instrumen. Uji coba instrumen dilakukan untuk mendapatkan kualitas tes yang valid dan dapat dipercaya. Instrumen yang baik harus mempunyai persyaratan sebagai berikut: (1) validitas.

Sudaryono (2012) validitas adalah adalah suatu konsep yang berkaitan dengan sejauh mana tes yang telah mengukur apa yang seharusnya diukur. (2) reliabilitas, yang tinggi sehingga soal tersebut dapat dipercaya untuk digunakan sebagai alat pengumpul data. (3) daya pembeda

Daryanto (2010) Daya pembeda soal adalah kemampuan suatu soal untuk membedakan antara siswa yang pandai dengan siswa yang kurang pandai. (4) Tingkat Kesukaran, soal yang baik adalah soal yang tidak terlalu mudah dan tidak terlalu susah. Berdasarkan uji syarat di atas didapatlah 6 soal yang dapat digunakan sebagai instrumen penelitian. Kemudian dilakukan uji hipotesis dengan menggunakan rumus uji-t dengan menggunakan rumus uji-t dengan rumus sebagai berikut:

$t=\frac{\bar{x}-\mu_{0}}{\frac{s}{\sqrt{n}}} \quad$ (Sugiyono, 2014)

untuk mengetahui apakah hipotesis penelitian diterima atau ditolak. Menurut Purwanto (2010) untuk menilai hasil aktivitas belajar siswa selama proses pembelajaran dengan menggunakan model pembelajaran Quantum Teaching dilakukan dengan menggunakan persen atau percentages correction sebagai berikut:

$$
N P=\frac{R}{S M} \times 100 \%
$$




\section{HASIL DAN PEMBAHASAN}

Penelitian ini dilaksanakan langsung oleh peneliti pada tanggal 25 Agustus sampai 25 September 2017 di SMK Negeri 3 Lubuklinggau. Jumlah pertemuan tatap muka yang dilaksanakan adalah empat kali pertemuan dengan rincian satu kali pre-test selanjutnya dua kali perlakuan dengan menggunakan model pembelajaran Quantum Teaching setelah itu satu kali post-test.

Pada pelaksanaan pre-test didapat hasil nilai siswa dengan nilai tertinggi 57 dan nilai terendah 10 . Hal ini menunjukan bahwa belum ada siswa yang mendapatkan nilai lebih atau sama dengan nilai KKM yaitu 75 .

Selanjutnya pada pelaksanaan posttest didapat hasil siswa dengan nilai tertinggi 98 dan nilai terendah 59. Hal ini menunjukan bahwa 30 siswa sudah dikatakan tuntas karena nilainya sudah mencapai nilai KKM yaitu 75 dan sebanyak 6 siswa yang nilainya belum tuntas dikarena nilainya tidak mencapai KKM.

Uji normalitas data dilakukan pada data pre-test dan post-test, hasil uji normalitas data tersebut dapat dilihat pada tabel 2 .

Tabel 2. Uji Normalitas Data

\begin{tabular}{|c|c|c|c|}
\hline Data & $\chi_{\text {hitung }}^{2}$ & $\chi_{\text {tabel }}^{2}$ & Kesimpulan \\
\hline $\begin{array}{l}\text { pre- } \\
\text { test }\end{array}$ & 4,17 & 12,59 & Normal \\
\hline $\begin{array}{c}\text { post- } \\
\text { test }\end{array}$ & 3,52 & 12,59 & Normal \\
\hline
\end{tabular}

Berdasarkan tabel di atas dengan ketentuan pengujian menggunakan rumus Chi-Kuadrat dengan $\mathrm{dk}=35$ dapat disimpulkan bahwa data pre-test dan posttest berdistribusi normal.

Setelah mengetahui data berdistrubis normal maka tahap selanjutnya adalah menguji hipotesis. Berdasarkan perhitungan yang diperoleh $\mathrm{t}_{\text {hitung }}=4,367$ dan $\mathrm{t}_{\text {tabel }}=1,6973$ karena $t_{\text {hitung }}>t_{\text {tabel }}$ Dengan demikian $\mathrm{H}_{\mathrm{a}}$ diterima dan $\mathrm{H}_{0}$ ditolak. Sehingga dapat disimpulkan bahwa hipotesis yang diajukan dapat diterima kebenarannya. Peningkatan hasil belajar dapat dilihat pada gambar 1 .

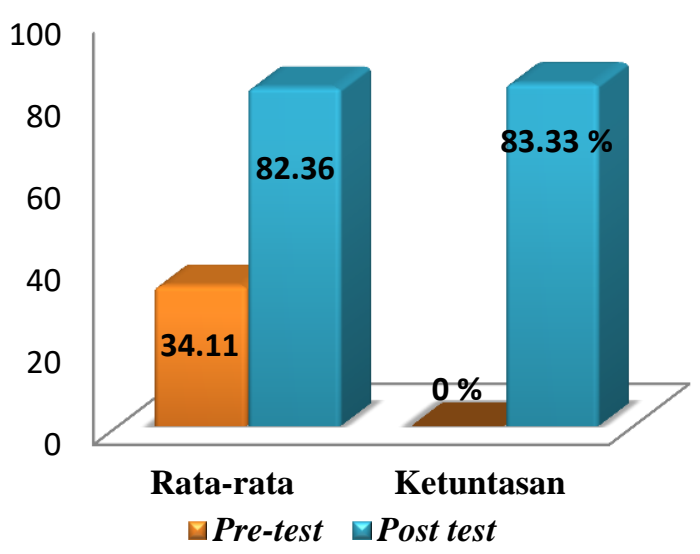

Gambar 1. Grafik Peningkatan Hasil Belajar

Observasi dalam penelitian ini digunakan untuk mengetahui aktivitas belajar siswa dalam proses pembelajaran di dalam kelas dengan menggunakan model pembelajaran Quantum Teaching pada pembelajaran fisika materi gerak yang kemudian diperhatikan oleh 4 observer. Deskripsi aktivitas belajar siswa selama proses pembelajaran dengan menggunakan Quantum Teaching dapat dilihat pada tabel 3 .

Tabel 3. Persentase aktivitas siswa

\begin{tabular}{llllll}
\hline & Ob.1 & Ob.2 & Ob. 3 & $\begin{array}{l}\text { Ob. } \\
\mathbf{4}\end{array}$ & $\begin{array}{l}\text { Rata- } \\
\text { rata }\end{array}$ \\
\hline Per.1 & $65 \%$ & $77 \%$ & $70 \%$ & $67 \%$ & $68 \%$ \\
\hline Per.2 & $77 \%$ & $80 \%$ & $82 \%$ & $77 \%$ & $76 \%$ \\
\hline
\end{tabular}

Dari tabel di atas pada pertemuan pertama rata-rata aktivitas siswa sebesar 68\% dalam kategori cukup dan pada pertemuan kedua rata-rata aktivitas belajar siswa sebesar $76 \%$ dalam kategori baik. Dengan demikian kegiatan siswa pada pertemuan kedua meningkat sebanyak $11 \%$. Peningkatan aktivitas belajar siswa dapat dilihat pada gambar 2 . 


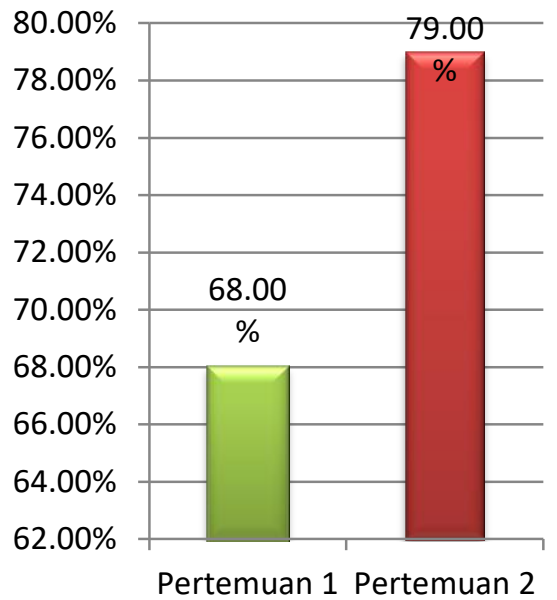

Gambar 2. Grafik Peningkatan Aktivitas Siswa

Berdasarkan perhitungan dengan menggunakan uji-t diperoleh $\mathrm{t}_{\text {hitung }}=$ 4,367 dan $t_{\text {tabel }}=1,6973$ karena $t_{\text {hitung }}>t_{\text {tabel }}$ Dengan demikian $\mathrm{H}_{\mathrm{a}}$ diterima dan $\mathrm{H}_{0}$ ditolak. Dengan demikian hipotesis yang berbunyi "Rata-rata hasil belajar siswa setelah mengikuti pembelajaran siswa dengan menggunakan model pembelajaran Quantum Teaching lebih dari atau sama dengan $75(\mu \geq 75)$." dapat diterima.

Dari hasil pengamatan aktivitas siswa pada proses pembelajaran dengan menggunakan model pembelajaran Quantum Teaching pada pertemuan pertama rata-rata aktivitas siswa sebesar 68\% dalam kategori cukup dan pada pertemuan kedua rata-rata aktivitas siswa sebesar $79 \%$ dalam kategori baik.

Dari pertemuan pertama dan pertemuan kedua aktivitas belajar siswa meningkat sebanyak $11 \%$. Dengan demikian terdapat peningkatan aktivitas belajar siswa dalam mengikuti pembelajaran dengan menggunakan model pembelajaran Quantum Teaching.

\section{SIMPULAN}

Berdasarkan data hasil penelitian dan pembahasan, diperoleh bahwa Berdasarkan hasil analisis uji-t diperoleh $t_{\text {hitung }}=4,206>t_{\text {tabel }}=1,6973$ karena $t_{\text {hitung }}>t_{\text {tabel }}$ dengan demikian $\mathrm{H}_{\mathrm{a}}$ diterima dan $\mathrm{H}_{0}$ ditolak. Nilai rata-rata hasil belajar post-test siswa sebesar 82,36 dan siswa yang tuntas mencapai 86,11 maka dapat disimpulkan bahwa penggunaan model pembelajaran Quantum Teaching efektif terhadap hasil belajar fisika siswa kelas X TKJ 1 SMK Negeri 3 Lubuklinggau tahun pelajaran 2017/2018 dan aktivitas belajar siswa pada saat proses pembelajaran fisika selama diterapkan menggunakan model pembelajaran Quantum Teaching di kelas $X$ TKJ 1 SMK Negeri 3 Lubuklinggau tahun pelajaran 2017/2018 meningkat aktif.

\section{DAFTAR PUSTAKA}

Arikunto, Suharsimi. (2010). Prosedur Penelitian Suatu Pendekatan Praktek. Jakarta: Rineka Cipta.

Arikunto, Suharsimi. (2013). Manajemen Penelitian. Jakarta: Rineka Cipta.

Deporter, Bobbi. (2014). Quantum Teaching (1999). (Ary Nilandari). Bandung: Kaifa.

Daryanto. (2010). Evaluasi pendidikan. Jakarta: Rineka Cipta.

Hertanti, Juita I. (2013). Meningkatkan Hasil Belajar Siswa Pada Pokok Bahasan Pemuaian Zat Melalui Penerapan Model Quantum Teaching. Berkala Ilmiah Pendidikan Fisika, 1 (2), 136-144.

Purwanto, Ngalim. (2010). PrinsipPrinsip dan Teknik Evaluasi Pengajaran. Bandung: PT Remaja Rosdakarya.

Rusman. (2014). Model-Model Pembelajaran: Mengembangkan Profesionalisme Guru. Jakarta: Rajawali. 
Siregar, Idres Hidayana \& Juliani, Rita. (2014). Pengaruh Model Pembelajaran Quantum Teaching terhadap Hasil Belajar Siswa Pada Materi Pokok Zat dan Wujudnya di Kelas VII Semester 1 SMP Negeri 3 Percut Sei Tuan Tahun Pelajaran 2013/2014. Jurnal Fisika, 2 (2), 9199.

Sudaryono. (2012). Dasar-Dasar Evaluasi Pembelajaran. Yogyakarta: Graha Ilmu.

Sugiyono. (2014). Statistika Untuk Penelitian. Bandung: Alfabeta. 